Момир Самарџић

Универзитет у Новом Саду

Филозофски факултет

Одсек за историју

samomomir@yahoo.com
Оригиналан научни рад

примљено: 1. јул 2012

прихваћено: 1. октобар 2012

\title{
ПРОТОКОЛ СЕДНИЦЕ ДРЖАВНОГ САВЕТА ОД 12/24. ОКТОБРА 1855. ПРИЛОГ ИСТРАЖИВАЫУ ЖЕЛЕЗНИЧКЕ ПОЛИТИКЕ УСТАВОБРАНИТЕЉА
}

Сажетак: Рад је посвећен седници Државног савета од 12/24. октобра 1855. као једном од најзначајнијих тренутака у артикулацији државне политике Кнежевине Србије према идеји изградње трансбалканске железнице. У прилогу доносимо целовит текст протокола седнице Државног савета.

Кључне речи: Државни савет, уставобранитељи, Србија, модернизација, трансбалканска железница, 1855.

Један од раних повесничара српске железнице Петар Миленковић ${ }^{1}$ први је, и до данас једини, истраживач железничке политике „уставобранитељске Србије“ на основу архивских фондова Државног савета, уз кнеза Александра Карађорђевића најзначајније институције власти. ${ }^{2}$ у студији Историја грађења железница $и$ железничка политика код нас (1850-1935), осврћући се на настојања владајућих кругова у Србији да у јесен 1855. заштите државне интересе у вези са најављеном изградњом трансбалканске железнице Истанбул-Београд, Миленковић је кратко поменуо делатност Државног савета у септембру 1855, односно његово решење „на (...) седници 12. октобра 1855 год. (...): да се тражи од Великих Сила да оне дејствују

\footnotetext{
${ }^{1}$ Први покушај реконструкције настојања српске државе ка изградњи железнице представљало је дело Тасе Ђ. Ивковића (Споменица двадесетпетогодишњице српских државних железница. Од 3. Септембра 1884. до 3. Септембра 1909. год), пригодно настало 1909, поводом двадесетпетогодишњице отварања линије Београд-Ниш, прве железнице у Србији. После Првог светског рата прво је Драгомир Арнаутовић 1934. објавио преглед историје изградње српске железнице (Историја српских железница од 1850. до 1918. г), да би убрзо, 1936, као трећа, била објављена Миленковићева студија Историја грађења железница и железничка политика код нас (1850-1935).

${ }^{2}$ Миленковић при томе у фусноти 1 на страни 14 наводи да је користио исписе Алексе Јовановића из архивског фонда Државног савета, односно да сам није истраживао грађу поменуте државне институције.
} 
на Високу Порту, да се Србији дозволи да сама прави уговоре и да даје концесије за грађење железнице кроз Србију““. ${ }^{3}$ Иако суштински тачно одражава један сегмент актуелног питања, Миленковићев паушални помен недовољно квалитетно детерминише место седнице Савета у дефинисању државне стратегије усмерене ка заштити интереса османске вазалне Кнежевине Србије. У том смислу, седница Савета од 12/24. октобра 1855, занемарена од каснијих истраживача историје српске железнице упркос Миленковићевом помену, има изузетан значај у истраживачким настојањима реконструкције осмишљавања дугорочне концепције државне стратегије у вези са позиционирањем Србије и њених интереса у контексту актуелних пројеката трансбалканске железнице, предвиђених да пређу преко њене територије.

Приликом контекстуализације места и значаја поменуте седнице, неопходно је поћи од констатације да је појављивање железничког питања у српској политици уопште, па и у јесен 1855, било спољнополитички условљено, те га је потребно посматрати кроз призму односа великих сила и Османског царства средином 19. века, односно настојања западних сила, пре свега Велике Британије, да изградњом неопходне саобраћајне инфраструктуре убрзају процес привредне трансформације Османског царства са крајњим циљем његове потпуне инкорпорације у оквире светског капиталистичког система постизањем компатибилности са захтевима капиталистичке економије, обезбеђујући сировинску базу за даљи успон западноевропске индустрије. ${ }^{4}$ Остварењу идеје изградње трансбалканске железнице пре Кримског рата, британски финансијери били су најближе почетком педесетих година, а Порта је у пролеће 1852 први пут британским инжењерима одобрила проучавање трасе линије Истанбул-Београд. ${ }^{5}$ Негативно расположена према целокупном концепту страних улагања, односно узимања дугорочних зајмова, Порта није желела да преузме обавезе на које није била приморана, те су покушаји почетком педесетих пропали.

Тек савезништво Велике Британије и Француске са Османским царством у рату против Русије 1854-1855. ослабило је османски отпор привредним уступцима и отворило је врата страном капиталу. Прихватајући зајмове које су савезници наметнули, на Порти су постепено губили и могућност да се супротставе понудама

\footnotetext{
${ }^{3}$ П. Миленковић, нав. дело, 14. Каснији аутори прегледа историје српске железнице који су помињали железничку политику уставобранитеља(Dragomir Arnaoutovich, Histoire des chemins de fer Yougoslaves 1825-1937, Paris 1937, 48; Јездимир С. Николић, Историја железнииа Србије, Војводине, Црне Горе и Косова, Београд 1980, 35), па и Даница Милић која је написала доскора једини рад фокусиран на уставобранитељску време у контексту идеја за изградњу трансбалканске железнице (D. Milić, Die Pläne zum ausbau der Eisenbahn in Serbien in der Mitte des 19. Jahrhunderts, Eisenbahnbau und Kapitalinteressen in der Beziehungen der Österreichischen mit den Südslawischen Ländern (Hrsg. R. G. Plaschka), Wien 1993, 33), ослањали су се на Миленковићеве наводе, без додатног истраживања.

${ }^{4}$ Immanuel Wallerstein, Hale Decdeli, Reşat Kasaba, The incorporation of the Ottoman Empire into the worldeconomy, The Ottoman Empire and the World Economy (Ed. H. İslamoğlu İnan), Cambridge 2004, 88-95; Reşat Kasaba, The Ottoman Empire and the world economy: the nineteenth century, New York 1988, 4-6, 35-36.

${ }^{5}$ Момир Самарџић, Суочавање са модернизачијским изазовом: британски инфраструктурни пројекти на Балкану 1851-1852. и Србија, Истраживања 22 (2011), 264. У наведеном раду налазе се детаљна анализа старије литературе и извора о британски напорима почетком педесетих година 19. века.
} 
за улагање капитала и ангажовање страних стручњака. Страни финансијски саветници придружени су државној благајни, а група западних инжењера одређена је да саветује Савет танзимата о неопходним јавним радовима. ${ }^{6}$ Под њиховим утицајем, Савет танзимата је почетком септембра 1855. истакао значај развоја саобраћајне инфраструктуре, односно изградње железница, за привредни развој царства и његово повезивање с Европом. Линија Истанбул-Београд посебно је поменута као начин на који би ово питање могло да буде решено. ${ }^{7}$ Убрзо су објављени у прецизни услови за уступање концесије за изградњу железнице - било је предвиђено да друштво подлеже османским законима, односно да евентуални судски спорови између друштва и Порте буду суђени пред османским судовима, грађење и експлоатацију требало је да надзире Порта, у њеном власништву остало би земљиште на којем би железница била изграђена, док би коришћење дрвене грађе и угњенокопа уз трасу било уступљено друштву на основу накнадног споразума са Портом. ${ }^{8}$

Српски кнез Александар, Државни савет и министри пажљиво су током 1855. пратили развој догађаја у Истанбулу, као и писање стране штампе у вези са давањем концесије за изградњу линије до Београда, а изјава Савета танзимата којом се предност даје овој линији, као и пратеће вести, нашле су своје место на страницама Србских новина. ${ }^{9}$ Из текста услова за давање концесије било је лако уочити да Порта намерава да располаже земљиштем и природним богатствима Србије не водећи рачуна о њеном аутономном статусу, односно да вазални положај Србије не сматра ограничењем за самостално одлучивање о овом питању. Развој догађаја указивао је на постојање одређених разлика у односу на 1852, јер тада није постојала начелно изражена спремност Порте да приступи коначном решавању питања трансбалканке железнице. Непосредан позив страним финансијерима, као и осмишљени услови концесије, упућивали су на одлучност Порте да гради железницу ка Београду, и то без учешћа Србије у преговорима о концесији.

Седница Државног савета од 12/24. октобра представљала је важну тачку у дефинисању стратегије отпора намерама Порте. Негативан став и намера Србије да самостално одлучује о изградњи железнице на властитој територији, као основе државне политике, дефинисани су већ 1852. у првим контактима кнеза Александра и страних дипломатских представника у Београду. ${ }^{10}$ Оквири нове саобраћајне

\footnotetext{
${ }^{6}$ Gerhard Rosegger, John H. Jensen, British Railway Builders along the Lower Danube 1856-1869, The Slavonic and East European Review, Volume XLVI, Number 106 (January 1968), 106-108.

7 Walter Rechberger, Zur Geschichte der Orientbahnen: Ein Beitrag zur österreichisch-ungarischen Eisenbahnpolitik auf dem Balkan in den Jahren von 1852-1888, Wien 1958, рукопис докторске дисертације, 29; Србске новине, бр. 102, 7. септембар 1855.

${ }^{8}$ Србске новине, бр. 111, 1. октобар 1855.

${ }^{9}$ Исто, бр. 101, 6. септембар 1855; бр. 102, 7. септембар 1855; бр. 111, 1. октобар 1855.

${ }^{10}$ М. Самарџић, нав. дело, 264-273. Том приликом водећа личност у усмеравању државне политике у вези са овим питањем био је кнез Александар, док не постоје сачувани подаци да се о железници формално расправљало у оквиру Државног савета. У познатим сачуваним изворима, односно фондовима државних институција из 1852, нисмо пронашли ниједан податак о железници, како о доласку страних инжењера, тако и о ставу владајућих кругова у Београду. Није познато на основу којих извора је Таса . Ивковић писао о ставу Србије почетком педесетих година 19. века, али је на основу извештаја страних
} 
политике Порте, формулисани почетком септембра 1855, наметнули су неопходност конкретизације државне политике и јасно формулисање става према Портиним намерама. Убрзо после написа у страној штампи и пријема вести од српског капућехаје у Истанбулу Константина Николајевића, уследила је седница Државног савета од 13/25. септембра, прва званична седница на којој је било речи о изградњи железнице. $^{11}$ Дефинисање државних интереса у контексту очувања постојећих аутономних права водило је, после кореспонденције са Попечитељством иностраних дела и капућехајом, ${ }^{12}$ ка седници 12/24. октобра.

Николајевићев извештај из османске престонице о разговору са Фуадпашом, министром иностраних дела, указивао је на одлучан став Порте да Србија нити има право сама да гради железницу у Србији, нити сме да преговара са страним компанијама о уступању концесије, а да ће свако противљење намерама Порте водити заобилажењу Србије повезивањем са аустријским железницама преко Видина. Фуад-пашин став као два најзначајнија питања расправљана на седници Савета 12/24. октобра одредио је право Србије да самостално гради железницу и са тим циљем уступи концесију страним друштвима. Полазећи од међународноправног статуса у којем се Србија налазила, чланови Савета оквире супротстављања намерама Порте тражили су у актима на којима је њен аутономни положај био утемељен - хатишерифима из 1830. и 1833, односно „Турском“ уставу, хатишерифу из 1838. У одбрани права Србије да самостално одлучује о градњи железнице, Савет је полазио од члана 5. хатишерифа из 1830, који Србији даје слободу деловања у унутрашњим пословима, односно чланова 50. и 51. „Турског“ устава, којима се грађење путева такође одређује као њено унутрашње право. Одбрану права на самостално преговарање Савет је темељио на члану 5. Устава којим је кнезу дозвољено оснивање „особене Канцеларије“, темеља будућег Министарског савета, односно владе, задужене између осталог, преко Попечитељства иностраних дела, за односе са страним државама, као и на постојећој пракси сарадње са страним привредницима током процеса механизације првих индустријских погона у Србији. Поред тога, чланови Савета полазили су од става да је правним актима утврђена унутрашња аутономија неостваривим чинила сваки покушај уступања земљишта, коришћења материјалних добара и организације експлоатације, уз подразумевајући полицијски надзор. ${ }^{13}$ Другим речима, став Државног савета био је у целини супротстављен ставовима Порте, а седница 12/24.

дипломатских представника у Београду, као јединог познатог извора за реконструкцију ставова владе у вези са овим питањем 1852, јасно да су Ивковићеви наводи или погрешни или спорни без ишчитавања нових извора. (М. Самарџић, нав. дело, 264-265 (фуснота 56), 268 (фусноте 71 и 72)

${ }^{11}$ Протокол седнице Државног савета од 13/25. септембра 1855, № 1105, Архив Србије (=АС), Државни савет (=ДС), 1855, Протоколи седница. Вест о одлуци Савета танзимата први пут се помиње у Србским новинама од 6/18. септембра 1855 , да би детаљно била образложена у следећем броју, 7/19. септембра. Реакција Државног савета уследила већ на седници 13/25. септембра.

12 Државни савет Попечитељству иностраних дела, Београд 13. септембра 1855, АС, ДС, П№ 465/855; Попечитељство иностраних дела Државном савету, Београд 24. септембра 1855, исто; протокол седнице Државног савета од 30. септембра/12. октобра 1855, № 1173, АС, ДС, 1855, Протоколи седница.

${ }^{13}$ Протокол седнице од 12/24. октобра 1855 , АС, ДС, 1855 , Протоколи седница. 
октобра представљала је до тада најзначајнији тренутак артикулације политике Србије у вези са пројектом трансбалканске железнице. Имајући у виду чињеницу да су основе утврђене на наведеној седници остале основе железничке политике Кнежевине током више од две деценије, односно до стицања независности 1878 , сачувани протокол представља изузетно значајан извор у реконструкцији развоја државне политике према једном од значајнијих питања којим се српска дипломатија бавила све до осамдесетих година 19. века - обезбеђењу места Србије на траси трансбалканске железнице.

Полазећи од раније наведеног, као и од чињенице да, поред Миленковића који је користио само извод грађе архивских фондова Државног савета, српска историографија није имала прилику да се упозна са овим изузетно интересантним историјским извором, у прилогу доносимо целокупан текст протокола седнице Државног савета од 12/24. октобра 1855. Документ се чува у Архиву Србије, фонд Државни савет и има обим од 17 страна. Доносимо га у оригиналу, уз неопходне интервенције у оквиру угластих заграда.

Протоколль совьтования

Главно Засьданіс

№ 1228

12. Октобрія 1855.

У Бъограду

У союзу са извђстіємъ П[о]п[е]ч[и]т[е]лства Инностранны’ Дъла', подъ 24. Септемврія т. г. П№ $3101,{ }^{14}$ Совъту поднешенномъ, ${ }^{15}$ да $є$ оно подсредствомъ србскогъ Капићехає већъ чинило сходне кораке кодъ високе Порте къ предохранъню земальскогъ права собственне автономіє у предмету грађеня гвозденногъ пута крозъ Сербію наспрамъ намъре високе Порте, у званичномъ Цариградскомъ листу пре краткогъ времена обявльне, ${ }^{16}$ градити гвозденный путь одъ Цариграда до Бъограда, за предузеће чега она є и разне Компагніє (инностране) явно позвала, Княжескій Представникъ и Попечитель Иностраны' Дъла', Г. Алекса Симићъ, саобштіо є Совъту извъстія Капи-ћехає у предмету. ${ }^{17}$

Капићехая явля, како $є$ имао по овомъ предмету дугу конференцию съ г. Фуадъ-Пашомъ, Министромъ Иностранны' Дьла' Бл[ыстателне] Порте, коє є резултатъ био неповолянъ, и у коіой є Фуадъ-Пашаъ у суштественности умствовао овако:

„У ствари, о коіой є вопросъ, имаю се разликовати призрьнія начела, и призрьнія аппликаціє. Посльдня само могусе саюжавати са призрьніяма наши' внутренны' права; преимућства' и автономіє; а што се годъ тиче отношенія између странаца и оттомански’ Држава, и ма какви’ концессія' и повластица' странцима у овым државама, то спада подъ режимъ трактата; у надлежность централногъ

\footnotetext{
${ }^{14}$ Извештај Попечитељства иностраних дела о првим корацима на Порти од 24. септембра/6. октобра 1855. чува се у под сигнатуром АС, ДС, П№ 465/855.

${ }^{15}$ Протокол седнице Државног савета од 30. септембра/12. октобра 1855, АС, ДС, 1855, Протоколи седница.

${ }^{16}$ Реч је о тексту објављеном у часопису Журнал де Константинопл (Journal de Constantinople) 29. августа/10. септембра 1855, пренетом у Србским новинама 7/19. септембра 1855.

${ }^{17}$ Николајевићев извештај није сачуван, али се може претпоставити да је, према уобичајеној пракси у административној преписци, у протоколу седнице Савета изложен готово у целини.
} 
суверенскогъ Правителства. Тако н. пр. по овымъ начелама вазаллске државе не само нису властне са странцима ништа трактирати, или овима икакве повластице уступати безъ нарочногъ саизвольня Портиногъ, него не могусе ни пртивити, да Порта то сама, кад' по свомъ собственномъ побуђеню нађе за добро, у ны'овимъ земляма као саставнимъ частима царства, чини.

Тако и концессіє гвозденны' путова страннымъ Компагніяма, было то у непосредственнымъ, было у вазаллскимъ областима, она $є$ єдина надлежна допуштати кад' се предлажу иниціятивомъ вазаллски' Правителства', и предписивати ій овыма за признаванъ, кад' ій она сама по своіой собственной иниціятиви презъ уговоре допушта. Режимъ привилегія', повлашћены' вопроснымъ државама, не може ни наймане ову вр'овну властъ нъну ограничавати, но само у толико може быти говора и особенийъ опредъльня при оваквимъ пословима, да се вазаллскимъ државама осигураю за ны'овъ собственный рачунъ користи одъ оне части грађевине овогъ рада коє се буду у границама ны'овы земаля извршиле.

За подкрьпльнъ положеня овогъ навео є Фуадъ-Паша примъръ гвозденногъ пута Египатскогъ, сад’ у проєкту стоєћегъ канала Суецскогъ, єдну скорашню концессію Портину нъкой Компагніи за построђнъ подморскогъ Телеграфа одъ Цариграда до Александріє, и одандъ преко Егіпта до восточне Индіє, и найпосль примъръ Француске компагніє мобиліярногь кредита, ${ }^{18}$ коя $\epsilon$ непосредственно предлагала Молдавскомъ Князу, да она начини гвозденный путъ крозъ Молдавію одъ Аустрійске границе до Галаца. У свимъ овимъ случаима, говоріо $\epsilon$ онъ, Порта $є$ себи задржала власть предварителногъ разсмотреня и одобреня, одъ коє є већъ и употребльнъ учинила при послу гвозденногъ пута Египатскогъ и садашнъ концессіє подморскогъ Телеграфа. И ова последня да може їшт' служити за примъръ и темель, како се грађенъ гвозденногъ пута одъ Цариграда до БЪограда съ нама може регулирати. Начело є спрама Египта то поставльно да вицекраль мора допустити построђніє линіє телеграфическе преко нъговогъ территориума съ Портомъ трактировшой Компагніи, а приходе одъ ове части линіє онъ ће самъ имати право сабрати за свой рачунъ. Тако дакле и толико и нама бы се могло одъ наше части гвозденногъ пута оставити.“

Кад є на ова умствованя Фуадъ-Пашина Србскій Капи-ћехая сходна возражанія давао, Фуадъ-Паша є найпосль казао да ниє пробытачно за Србско Правльніє, не соглашаватисе у предмету съ начелима Порте, єръ у таквомъ случаю или ћесе она наћи принуђена, не узети у призръніє наша предлаганя, или овомъ путу другий правацъ дати, н. п. къ Видину, па ће то за нашу землю їшт већа и неоцънъна штета быти.

Изъ овогъ извђстія Капићехає видећи Совътъ, да умствованъ Г. ФуадъПаше иде на повреду наши' народны' права', и да $\epsilon$ нуждно постарати се о средствама къ предохраненю овы', важногь овогъ предмета ради сазвао $є$ данасъ Главно Засеьданіє, у комъ є предметъ посмотренъ 1., у отношеню къ праву Србскомъ на самограђень гвозденногъ пута крозъ Сербію, 2., у отношеню къ праву Србскомъ, чинити у томъ предузећу уговоре съ компагніяма иностранымъ:

Што се тиче првогъ питаня, оно є рьшено самымъ яснымъ текстомъ высочайши' Акта', коима су преимућства Народа Србскогъ осигурана, као преимућство внутренньгъ правльнія, у коє предметъ грађеня мостова, путова и друмова, безъ свакогъ изузиманя гвоздены', принадлежи, коє се право Устава Земальскогъ $\S \S^{\text {има }} 50$. и 51. изрично проглашує, као што тіи $\S \S^{\text {и }}$ гласе: „Трошкови, коє причинява садржанъ и уређенъ мостова и путова быће расположени на обштество села', коя су у околини“. „Тако исто, као што є Правленіє централно Княжества дужно имати управлянь и старанђ о великима друмовима, куда пролазе

\footnotetext{
${ }^{18}$ Реч је о паришкој финансијској кући Креди мобилије (Crédit mobilier).
} 
поште, о мостовима и о прочима обштеполезнима Зданіяма.“ По овомъ праву Сербія $\epsilon$ и досад' правила мостове, путове и друмове, нити їой ишта може быти на путу, правити и гвозденный путъ у внутреннъости своїой. И кад' бы она имала собственны' средства', она бы онако исто, као што є и досаданъ друмове своє правила, и као што $є$ у посльднъ време и Телеграфъ подигла, ${ }^{19}$ и гвозденный путъ у внутреньости Србіє не може быти сумнъ, тимъ манье, што и $\S 5^{\text {bй }}$ высочайшегъ Хаттишерифа одъ 1830. год. овако говори: „Власти не моє Високе Порте нећесе мъшати ни у унутрашня дела, ни у судейска ръшенія земль исте, ни шта выше захтьвати, ни аспре єдне, кромъ данка.“ Почемъ дакле грађенъ путова спада у кругъ внутренньгъ правльнія, и предузеће грађеня ны'овогъ може дати повод, къ

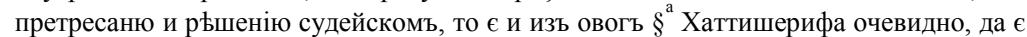
право грађеня свакогъ пута, сльдователно и гвозденногъ, чисто право Србско.

Но изъ извђстія Капи-ћехає и не видисе, да Г. Фуадъ-Паша само ово право Србско на грађенъ гвозденногъ пута крозъ Сербію оспорава, но видисе да онъ оспорава право Србско, правити уговоре и давати уступльня у предмету грађеня пута овогъ, и уобште у подобны предмета, иностраннымъ компагніяма. И то $є 2$. тачка вопроса, коя є у Главномъ засьданію, посмотрена.

Но и ова є тачка рышена самымъ рьшеніємъ прве тачке и яснымъ текстомъ высочайши' Акта' обезбђђаваюћи' преимућства Народа Србскогъ, и осимъ тога право ово освећено є дуготраюћомъ и многоплодномъ практикомъ.

По првомъ положеню шта бы значило горньимъ начиномъ доказано Србско право на грађенъ гвозденногъ пута, ако Србія не би могла безусловно ползоватисе ньиме? Ово ползованъ правомъ овымъ ограничило бысе яко ако Сербія не бы могла у нъговомъ упражняваню ползоватисе средствима иностранныма, и не бы было читаво, но было бы само полакъ права.

По другомъ положеню не само никаквымъ $\S^{\text {омъ }}$ предпохвальны' Царски' Аката' ниє прекраћено овакво Србско право, но напротивъ изрично изречено є земальскогъ Устава $\S^{\text {омъ }} 5$. $^{\text {имъ }}$ кои Князу Србскомъ говори: „Ти ћеш Теби устроити єдну особенну канцелларію, коя ће быти подъ управльнъмъ Твогъ мъстоблюстителя, Представника, коме ћешъ Ты наложити, издавати пасспорте, и управляти сношеніяма суштествуюћима између Срба и властій иностранны'.“ Природно рађасе питанъ, каквыма ће сношеніяма са иностранныма управляти Представникъ, ако неће то быти сношенія са предузимаюћим' Компагніяма Иностранным'? И како се може изводити изъ овогъ ясногъ и безусловногъ, а тако исто природно истакшегъ текста разлика каква између иностранны”? Текстъ $є$ изрекао сношенія съ властима Иностранныма, коє є далеко вышша и крђпчія мысао, неголи што су приватны иностранцы, и ко има право сношенія съ властима Иностранным', тимъ пре има са приватныма иностранным', природно слободныма, по себи допадаюћимасе условіяма ступити у погодбе са Србскимъ Правльніємъ.

Гдъ пакъ сама природа ствари, и положени закони говоре, ту изчезава свака Өеорія о смотреню начела и смотреню аппликаціє, тимъ пре, што $є$ у царскимъ Актима изрично предохранъно право высочественно Нъговогъ Величества, Султана, у Сербіи, но у комъ овакавъ принципъ, какавъ Г. Фуадъ-Паша изводи, никако не налазисе.

\footnotetext{
19 За време Кримског рата успостављена је телеграфска веза између западне Европе и Истанбула, једним делом прелазећи и територију Србије. Телеграфски законик донет је 20. јануара/1. фебруара 1855 (Сборникъ закона' и уредба', и уредбеннь' указа' изданы' у Княжеству Србіи. (Одъ пошетка 1854. до конща 1855. године.), VIII, Београд 1856, 50-51), а телеграфски саобраћај са Хабзбуршком монархијом на линији Београд-Земун успостављен је 15/27. марта исте године. (Модерна српска држава 1804-2004: хронологија, (Ур. Бранка Прпа), Београд 2004, 93)
} 
По трећемъ положеню ограничень овакво Србскогъ права одъ стране Вис[оке] Порте появилобысе као чрезычайна, у очи упадаюћа новость у Сербіи.

Србско є Правителство толике уговоре везивало не само са компагніяма, но и са Државама Иностраннымъ. Тако постоє уговори између Выс[окогъ] Двора Аустрійскогъ и Правльнія Србскогъ у смотреню союза Телеграфическогъ, у смотреню узаямногъ насльдованя обостранны' подданника', у смотреню даваня и приманя соли; тако є оно правило уговоре съ Аустрійскимъ и Французскимъ Правльніємъ за извъстна лица, коя $є$ одъ ньи' за своє службе изисквало. Съ приватныма пакъ компагніяма Аустрійскимъ, Енглескима и Белгійскима, правило є оно уговоре о добавляню разны' машина', и нькима $є$ покрай уговора давало уступльня, као у смотреню печеня поташе, и т. д.

Явно доказателство, да $\epsilon$ право ово Србско многородномъ и дуготрайномъ практикомъ освЂћено, и да бы ограничаванъ нЊгово по основима Г. Фуадъ-Паше у Сербіи чрезвычайнымъ появилосе.

После овы' посмотреня у основима приступлћно є къ посматраню предмета у овога извршеню, и нађено $\epsilon$, да бы нъгово извршень по основу Г. ФуадъПаше како за Вис[оку] Порту, тако и за саму компагнію коя бы се посла примила, наишло на ужасне, даже необориме тегобе.

За грађень гвозденногъ пута иштесе землъиште, иштесе материяль, иштесе надзираніє полицайно. Ни Правителство Выс[оке] Порте, ни приватни Турцы, немаю, и не могу имати изванъ градова и предградія Бъоградскогъ, никаквы' непокретны' добара, како по 11. точки Выс[очайшегъ] Хаттишерифа одъ 1830. год., гдъ се каже: „Кромъ гарнизона градова пребыванъ у Сербіи забранъно є свакомъ другомъ Турчину сасвимъ“, тако и по хатишшерифу одъ год. 1833. гдъ се каже: „Турцы неће ни кућа', нит’ ичега другогъ изванъ БЪоградскогъ предградія зидати“, и гдђ се иначе у оба Хаттишерифа каже да Турци своя непокретна добра изванъ градова имаю Србльима предати. По чему ни Выс[ока] Порта не може располагати ни земльиштемъ, ни майданима каменогъ угльна, о коима у свомъ программу говори, или съ другима майданима у Сербіи. Земль су собственност Правителства или приватны', матеріяль морасе набавляти у внутренньости, надзираніє є полицайно у Србіи Србско. Какви ће средства стояти на руци Выс[окой] Порти и компагніи мимо Правителства Србскогъ къ извршеню предузећа овогъ по реченнымъ отношеніямъ? Осимъ тога предузеће ово захтъва за себе посебный и особенный законъ. Ко ће издати у Сербіи мимо Правителства Србскогъ овакавъ законъ? Ко може осимъ Правителства Србскогъ, испытати и изнаћи, какавъ за Сербію приличи закон? И найпосль, ко мимо Правителства Србскогъ има право, и може у Сербіи извршавати законъ?

Найпосль Правителство Србско има на себи обвезатность, свима поступцима своима оправдати предъ народомъ Србскимъ повъренъ, съ коимъ земльомъ и народомъ управля. Каква ће средства имати она за ово оправдань у очима народа, кой зна, и у свомъ є праву свъстанъ, да внутренъ правленіє, и сношеніє съ иностранцима, куд' и грађенъ гвозденногъ пута, и погодба съ иностранным' компагніяма безспорно принадлеже, припада Правителству Сербскомъ? И немаюћи Правльніє никаквы' средства' къ оправданю єдногъ противуправногъ поступка свога, како ће моћи стояти добро за посльдице, изъ овога породитисе могуће?

По свемъ овомъ посмотреню нађено $є$, и да право грађеня гвозденногъ пута припада народу Србскомъ, и да є ньгово право, погодбе съ иностранныма компагніяма за ово предузеће чинити, и повластице овыма - безъда се дира право Выс[оке] Порте сузеренско издавати, неоспоримо, по чему є и рђшено,

Да Княжескій Представникъ предметъ овай разложи овде стануюћой Иностранны' высокы' Дворова, ємство за обдржанъ Србски' права' на себе узевши', 
Господи Консулима, и да ій умоли, да они ствар објасне относителнымъ посланицима у Цариграду съ молбом одъ стране Правльнія Србскогъ да они по праву реченногъ ємствованя, и по милости своїой моћнымъ ходатайствомъ своимъ подъйствую кодъ Выс[оке] Порте о предохранъню вопроногъ права Србскогъ, и да се Сербіи остави право уговоре правити и концесіє давати иностранымъ компагніяма коє бы се овогъ посла грађеня гвозденногъ пута крозъ Сербію примиле, па было то каква особита компагнія, было она съ коїомъ бы Выс[ока] Порта уговоръ за овай путъ од Цариграда до Србске границе заключила.

Уговоръ Выс[оке] Порте и уговоръ Сербіє неће моћи быти єднаки, почемъ моћиће на другий начинъ и у другомъ количеству компагніи дати спомагателны' средства', као земльишта, дрва', камена, каменогъ угльна, гвожђа, руку', новаца, нежели што ће овога свега дати Выс[ока] Порта.

Царски Хаттишерифи, одъ кои ранніи обезбеђаваю, а посльдный потврђує права народа Србскогъ са изгледомъ на ньино распространђнђ, ако Србльи, као свагда, остану верни и привржени Выс[окой] Порти, препуно ємствую добро споразумнънъ у предмету, тимъ већма, што є народъ Србскій у посльднъ критическо време засведочио свою върность и приверженостъ къ Выс[окой] Порти, и што $є$ тимъ заслужіо далеко пређе у изгледъ поставльно распространънъ, а не стъшнънъ свои’ права', какво Г. Фуадъ-Паша умствує.

Кад' Г. Г. Консули примесе тога ходатайства и буду стваръ препоручили относителнымъ посланицима, онда у истом смыслу и по овомъ протоколу Представникъ да да наставльніє Србском Капићехаи у Цариграду, съ препорукомъ, да онъ у истомъ смыслу говори и дъйствує съ дотичны' выс[окы'] Дворова Посланицима, и кад’ получи и ньіово участвованъ о ходатайство, онда да съ истим’ разлозима дъйствує кодъ Высоке Порте о целисходномъ предохранЊню вопросногъ права Србскогъ.

Протоколль овай поднети князу.

Предсьдатель Совьта: Стеф[ан] Стефановић 
Извори и литература:

Извори:

Архив Србије, Државни савет, 1855.

Архив Србије, Државни савет, 1855, Протоколи седница.

Сборникъ закона' и уредба', и уредбенны' указа' изданыл' у Княжеству Србіи. (Одъ почетка 1854. до кониа 1855. године.), VIII, Београд 1856.

Србске новине, 1855.

Литература:

Арнаутовић, Д., Историја српских железница од 1850. до 1918. г, Београд 1934.

Arnaoutovich, D., Histoire des chemins de fer Yougoslaves 1825-1937, Paris 1937.

Wallerstein, I., H. Decdeli, R. Kasaba, The incorporation of the Ottoman Empire into the worldeconomy, In: H. İslamoğlu İnan (Ed.), The Ottoman Empire and the World Economy (), Cambridge 2004, 88-95;

Ивковић, Т. Ђ., Споменииа двадесетпетогодишњице српских државних железница. Од 3. Септембра 1884. до 3. Септембра 1909. год, Београд 1909.

Kasaba, R., The Ottoman Empire and the world economy: the nineteenth century, New York 1988.

Миленковић, П., Историја грађења железница и железничка политика код нас (1850-1935), Београд 1936.

Milić, D., Die Pläne zum ausbau der Eisenbahn in Serbien in der Mitte des 19. Jahrhunderts, R. G. Plaschka (Hrsg.), Eisenbahnbau und Kapitalinteressen in der Beziehungen der Österreichischen mit den Südslawischen Ländern, Wien 1993, 31-41.

Николић, Ј. С., Историја железнииа Србије, Војводине, Црне Горе и Косова, Београд 1980.

Прпа, Б. (ур.), Модерна српска држава 1804-2004: хронологија, Београд 2004.

Rechberger, W., Zur Geschichte der Orientbahnen: Ein Beitrag zur österreichisch-ungarischen Eisenbahnpolitik auf dem Balkan in den Jahren von 1852-1888, Wien 1958, рукопис докторске дисертације.

Rosegger, G., J. H. Jensen, British Railway Builders along the Lower Danube 1856-1869, The Slavonic and East European Review, Volume XLVI, Number 106 (January 1968), 105-128.

Самарџић, М., Суочавање са модернизаиијским изазовом: британски инфраструктурни пројекти на Балкану 1851-1852. и Србија, Истраживања 22 (2011), 255-278. 


\title{
PROTOCOL OF THE MEETING OF THE NATIONAL COUNCIL FROM 12/24 OCTOBER 1855 A CONTRIBUTION TO THE STUDY OF THE RAILWAY POLICY OF CONSTITUTIONALISM
}

\begin{abstract}
Summary
Frameworks of the new transport policy of Porta after the Crimean War, which was formulated in September 1855 with the emphasis on the construction of the TransBalkans railways Istanbul-Belgrade, imposed the necessity of specifying the state policy of the Ottoman vassal Principality of Serbia, and clear formulation of attitudes toward Porta's intentions aimed at disruption of its autonomous rights. The meeting of the National Council from 12/24. October 1855 was an important point in the definition of the long-term concept of the national strategy regarding the positioning of Serbia and its interests in the context of the current railway project, determining the framework of the state policy over the next two decades.
\end{abstract}

Keywords: National Council, constitutionalism, Serbia, modernization, TransBalkans railways, 1855 